\title{
THE INCREASING OF BUSINESS CAPACITY OF TENANT OF PROCESSED FOOD PODUCTS IN SRAGEN STP GANESHA SUKOWATI
}

\author{
Rahmawati Rahmawati ${ }^{*}$, Dwi Nowo Martono ${ }^{2}$, Iyus Hendrawan ${ }^{3}$, Yuanita Indriani ${ }^{4}$, Budhi Heryanto ${ }^{5}$, Gatot \\ Rambi Hastoro ${ }^{6}$ \\ ${ }^{1}$ Food Technology Program, Sahid University, Jakarta, ${ }^{2}$ Environmental Engineering Program, Sahid University, \\ Jakarta, ${ }^{3}$ Mechanical Engineering Program, Institut Teknologi Indonesia, Serpong, ${ }^{4}$ Institut Manajemen \\ Koperasi Indonesia, Bandung, ${ }^{5}$ PT Shiddiq Sarana Mulya, Jakarta, ${ }^{6}$ LPPM Universitas Sahid, Jakarta. \\ *rahmafarasara@usahid.ac.id
}

\begin{abstract}
The Science Techno Park (STP) Ganesha Sukawati Sragen is one of the STP in Indonesia. The STP Ganesha Sukawati Program in Sragen is to increase the business capacity of the SMEs (Small and Medium Enterprises) that are selected as tenants. Business capacity building is carried out by providing training and mentoring on business legality, improvement of food processing processes, packaging and labels, simple bookkeeping, and provision of equipment assistance. The assistance results showed that tenant knowledge and skills increased by 30-40\% regarding: (1) business legality. This is indicated by the preparation of requirements related to the management of the legality of the business; (2) producing the Aloe veranata product. This is indicated by the resulting crisp texture of aloe vera products; (3) labels and packaging. This is indicated by the availability of labels with new designs that contain more complete information in accordance with the labeling regulations; (4) management and business governance. This is indicated by the tenants in preparing business bookkeeping and business plans that are feasible; (5) tenants receive the assistance in leasing the equipment to assist business development.
\end{abstract}

Keywords: business capacity, processed food products, Sragen, STP Ganesha Sukawati

\section{INTRODUCTION}

Science Techno Park (STP) Ganesha Sukawati Sragen, is one of the Techno Park that has been established to be developed by Ministry of Research, Technology and Higher Education of the Republic of Indonesia among the other 22 Techno Parks. The main purpose of building the Techno Park is to improve the competitiveness of the new business people that produced food product based on local potential and creative industries. STP Ganesha Sukawati, as well as other STPs, is funded by the central government and developed by the Ministry of Research, Technology and Higher Education. Food processing is one sector of concern.

The government is developing the food processing business because it has enormous potential to be developed and from year to year it contributes to increase the regional income. This is very important in creating national employment which is still one of the problems of high unemployment. Meanwhile, competition for processed food products circulating is increasingly and getting stringent due to the ASEAN, Asia and global free markets. This requires the entrepreneurs in the food processing sector to maintain the qualities and increases innovation in order to produce products that have a high quality and competitive in the local, national and international markets. The strategy carried out is by increasing the capacity of business actors in the field of food processing, in order to be able to produce the highly competitive products.

To increase the competitiveness of business people at STP Ganesha Sukowati Sragen, the government have seleted tenant. This activity involves local and central government. There were 19 tenants who participated in the initial selection, but only 11 qualified tenants were chosen. In general, from the 11 selected tenants, 8 tenants produce various types of chips and crackers, 2 tenants produce beverages in liquid and powder form, and 1 tenant produces rice. The 11 tenants used the local raw 
materials from around Sragen.

The problems encoutered by tenants vary, in general are a lack of knowledge regarding regulations related to production license, good food processing methods, labeling, business management, and improper use of equipment. To overcome this problems and increase business capacity and competitiveness of tenant products, it is necessary to: (1) improve the quality of existing products. This can be done using appropriate materials and eqipments in terms of process and capacity. This can increase the amount of production and reduce costs; (2) the use of the right type of packaging in order to extend the shelf life of the product; (3) improved packaging and label design to make it more attractive and fulfill food label regulations; (4) continuous development of new products in accordance with market demand. These efforts will be able to make the products produced become a superior products that are in demand by the market.

\section{THEORETICAL FRAMEWORK}

The STP is defined as an area that is managed professionally to improve the welfare of its members through the creation and enhancement of ecosystems that support innovation to increase the competitiveness of industries and institutions that are under its auspices. The STP aims to stimulate and manage the flow of knowledge and technology in universities, R \& D institutions, and industries that in their environment; facilitating the creation and growth of innovation-based companies through business incubation and spinoff processes, and providing services to increase the other added value, through the provision of high-quality of space and facilities.

Technopark is an integrated learning environment based on competency and skill, broad-minded and innovative. The concept of techno park starts from Stanford University, followed by several universities around the world to make permanent cooperation between government, universities, industry and markets. Technopark can be an arena for research and development for institutes, professors, college students, students and work on projects with profit sharing. Technopark is a comfortable environment for technology to be developed, innovated, demonstrated, developed and implemented. Technopark is built with research and development tasks, training, human resources, cooperation, products and services that can benefit the communities.

Technopark has the task of carrying out the preparation and implementation of policies in the field of training; technology research and development; producing and marketing goods / services as well as carrying out national and international cooperation in order to increase the function of the institution. The governmentsdevelopthe food processing business because it has enormous potential to be developed and from year to year it contributes to increase the regional income. This is very important in creating national employment which is still one of the problems of high unemployment. Meanwhile, competition for processed food products circulating is increasingly and getting stringent due to the ASEAN, Asia and global free markets. This requires the entrepreneurs in the food sector to maintain the qualities and increase innovation in order to produce products that have a high quality and competitive in local, national and international markets. The strategy carried out is by increasing the capacity of business actors in the field of food processing, in order to be able to produce highly competitive products.

The increasing of the competitiveness of processed food products can be done in various ways, including by (1) improving the quality of existing products. This can be done using appropriate materials and equipments in terms of process and capacity. This can increase the amount of production and reduce costs; (2) the use of the right type of packaging in order to extend the shelf life of the product; (3) improved packaging and label design to make it more attractive and fulfill food label regulations; (4) continuous to develop the new products in accordance with market demand. These efforts will be able to make the products produced become superior which consumers are interested in.

\section{METHOD}

\section{Material}

The equipment used in this activity is the processing equipment and packaging for nata Aloe vera 
product, that consisting of stainless steel pan, hand sealer, stove, lid, plastic packaging, plastic cup, scales, and labels. The raw material used for processing nata Aloevera products are Aloe vera, sugar, citric acid, calcium lactate, lychee flavor, sodium benzoate.

\section{Implementation Method}

The implementation of the business capacity development activities are carried out by providing training, practicing and mentoring to tenants. The material provided includes: (1) business legality; (2) producing nata Aloe vera; (3) labeling and packaging; (4) management and business governance; (5) tenants receive assistance in leasing equipment to assist business development.

\section{RESULT AND DISCUSSION}

The eleven tenants who passed the selection at the initial stage were Mrs. Sri Lestari with the Laras product brand, Mrs. Yawinah with the KFD product brand, Mrs. Nanik Sukoco with the Green Heart product brand, Mrs Herawati Utami Dewi with the $R H$ product brand, Mrs. Anik Purwanti with the " Ducrija " Crispy mushroom product brand, Mr. Riyas Prihanto with the goat milk powder products, Mr. Asmadi with the SETIA product brand, Mr. Maghfironi with the corn chips product, Mrs. Nanik Siswidyawati with the $N N$ Snack product brand, Mrs.Asih Sapto Retno Nugroho with the Khadijah product brand, and Mr. Budiharjo with products organic rice.

The results of interviews, discussions, and field visits obtained data that each tenan has a different problem, but generally tenan problems consist of: (1) Availability of non-continuous raw materials and various material properties; (2) Equipment that has limited capacity and is made from materials that do not meet GMP requirements; (3) The cutting process of raw material with different thickness; the addition of spices wich are not the same amount; do not use scales; many chip products are crushed; chips contain lots of oil;(4) Hand sealer packaging device which heating parts are quickly damaged; the automatic system in the continuous sealer is damaged; the plastic packaging is less sticky so packaging is often open itself; labeling and label design are not in accordance with the rules; the quality of labels (stickers) is low so its easy to remove; and (5) limited marketing area and business development due to lack of complete business licenses. From the above problems, tenants have determined the priority issues that want to be resolved in this activity, that are (1) improvement of the quality of existing products. This can be done using appropriate materials and equipments in terms of process and capacity; (2) the use of the right type of packaging in order to extend the shelf life of the product; (3) improved packaging and label design to make it more attractive and fulfill of food label regulations; (4) continuous development of new products in accordance with market demand. These efforts will be able to make the products produced become superior which consumers are interested in.

\section{Business Legality Assistance}

The 11 selected tenants, all have had a food production certificate (PIRT), but one tenant who produces goat powder milk has no MD certificate. Milk and dairy products must have an MD food production certificate because milk is including a high-risk food (BPOM 2017). In addition eight tenants do not have halal certificates and 3 tenants have not officially registered their trademarks to the Directorate General of Intellectual Property. Tenants want to know more about the importance of this legality. Based on this, tenants were given training / assistance regarding PIRT (Home Industry Food), MD (In-Trademark), Halal and Trademark.

Tenants were given training on the importance of legality, how to obtain it, the requirements that must be prepared and the costs to be paid (Figure 1). Before and after training begins tenants are given a number of questionnaires to find out how much the knowledge can be absorbed. This value can be used as monitoring and evaluation of activities. In addition, the results of the activities are indicated by the preparation of the requirements related to the management of halal certificates, brands, and MD. Tenants are assisted by the relevant agencies to take care of the legality according to their needs. 


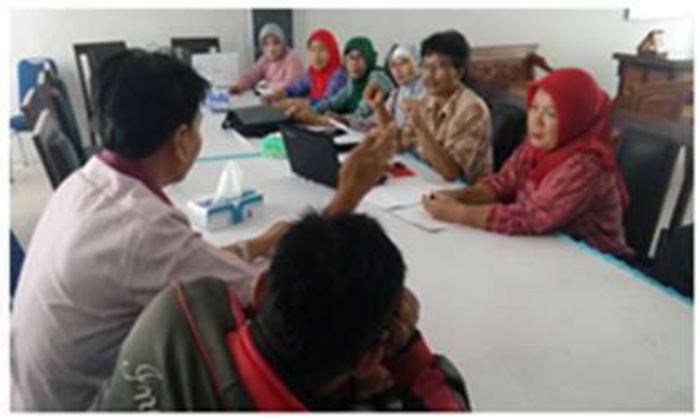

Figure 1. Business legality assistance

\section{Food Processing Assistance}

The nata Aloevera is one of the superior product in STP Sragen because the community likes it and tenants always get a lot of orders per week (50-100 cups). The weakness of this product were the texture is soft and has a shelf life only 2 days at room temperature. Tenants want to produce the crispy nata Aloevera products and have a shelf life of more than 2 days because it will make the marketing networks become wider. To improve this products, tenant is given training and practiced regarding the materials used, the correct processing and packaging (Figure 2). Tenant practiced to produce the nata aloe vera with the new formulations (Rahmawati et al. 2017). As a result of assistance, tenants can process the crispy of nata Aloevera that have a shelf life of more than 1 month, even though the product still feels acidic. Tenant must be reformulated to reduce the sour taste.

Besides that tenants informed us that they have limited Aloe vera plants. Based on this, tenant were given 50 Aloe vera trees. It is expected that tenants will have more raw materials so that they can increase production capacity and marketing reach.

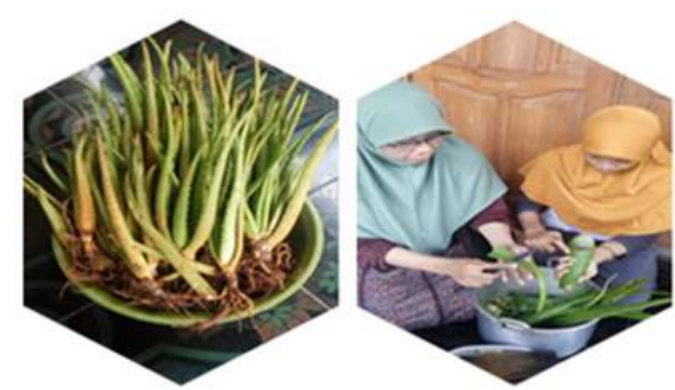

Figure 2. The assistance for planting Aloe vera seeds and processing of nata Aloe vera

\section{Packaging and Label Assistance}

Every food that will be traded to consumers must be included in the packaging. Food packaging aims to protect food from microorganisms and other contaminants. Food packaging can be in the form of plastic, paper, glass, metal alloys and others (BPOM RI 2007). In addition, every food product in a package must have an identity so that consumers know the condition and composition of the product. Product identity is written on the packaging surface. This identity is usually called as a label. Label is a medium of communication between business actors and consumers. Communication delivered must contain correct, clear and honest information. According to RI Law number 18 of 2012 concerning Food, especially article 97, the food label contains at least (1) product name; (2) list of ingredients used; (3) net weight or net contents; (4) name and address of the party producing or importing; (5) lawful (halal) for those required; (6) date and production code; (7) expiration date, month and year; (8) circulation permit number for Processed Food; and (9) the origin of certain food ingredients. 


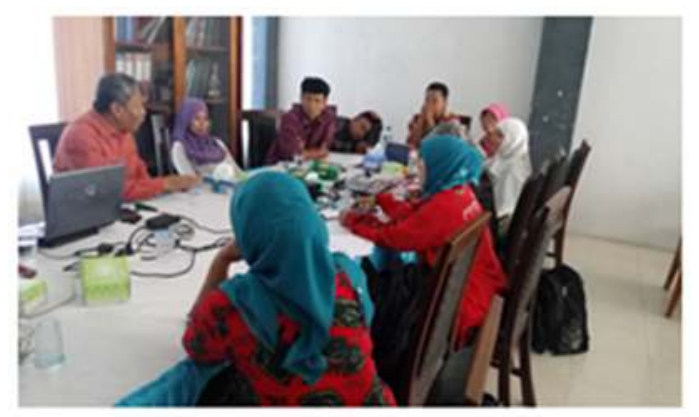

Figure3. Packaging and Label Assistance

The results of the previous evaluation found that most tenants still use improper packaging so that it caused the product not attractive. The average tenant still using thin plain plastic packaging which is less suitable for chips products. In addition, the labels used do not meet the requirements. Most of the tenants have written the brand, product name, composition of the ingredients only but not yet complete, writing the date of production and expiring but not yet filled (Figure 3 ).

The packaging needs to be considered because it protected the food from microorganisme that can destroy the food. Beside that the packaging is now also to be an important factor because it will attract consumers to choose the product and buy it. Consumers are also getting smarter in choosing products. They read the labels usually. Based on this, tenants were given assistance on the functions, roles and types of the packaging that suitable for their products. Tenants are also provided with the assistance of regarding food label regulations in accordance with BPOM regulations. After that tenants were given assistance to choose and design the new packaging that is in accordance with the products that have they produced and must apply food labeling regulations. The examples of the old packaging and the new one that have a result from the mentoring are presented in Figures 4 and 5.

\section{Simple Book keeping Assistance}

Making simple bookkeeping is useful for knowing the business development. So far, tenants have not recorded their business expenses and revenues well. Consequently the tenant did not know the true business profits. Therefore tenants were taught the simple bookkeeping and practiced of making it on this mentoring activities to manage their business. Thus it is expected that tenants can know the development of their business later. In addition, tenants were also accompanied to make a business plan for the development of a viable business. The results of this activity were each tenant has a simple bookkeeping of her/his business and a business plan for the development of her/his business.

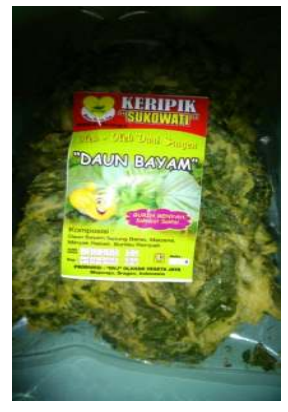

Old design

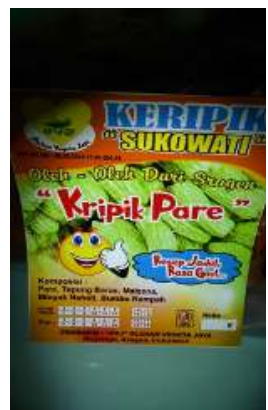

New design

Bitter melon chips

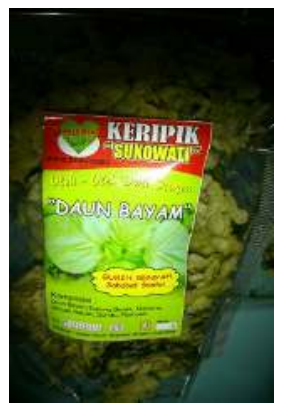

Old design

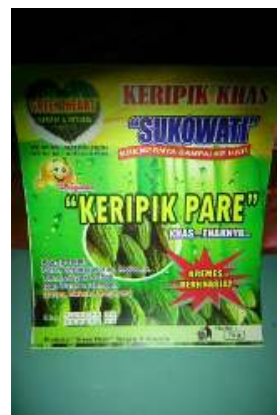

New design Spinach leaf chips

Figure 4. The old and new label design and brand for bitter mellon and spinach leaf chips 


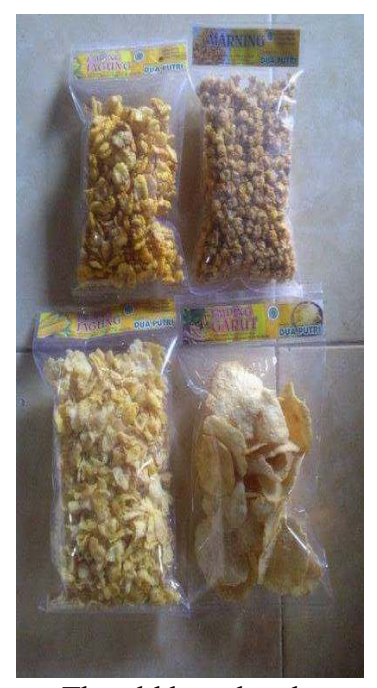

The old brand and packaging design

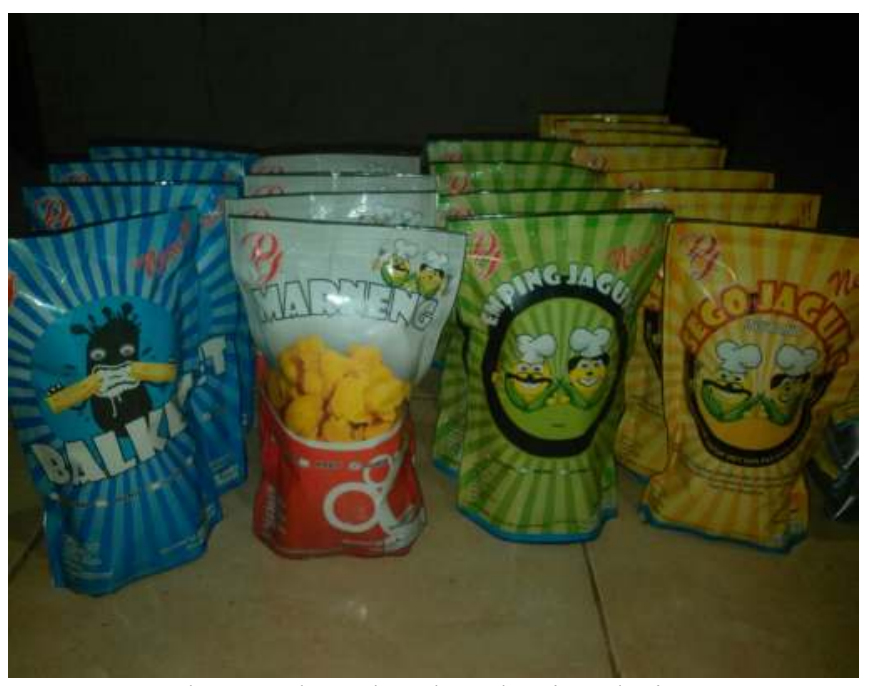

The new brand and packaging design

Figure 5. The old and new brand and packaging design for corn product

\section{Equipment Rental Assistance}

STP Ganesha Sukowati has leased equipments for the development of the tenants business. Equipments that were rented is not the same for each tenant because the equipment requirements of each tenant were different. The list of equipments that are leased for tenants were: (1) the slicer, digital scales, measuring cups, measuring spoons, and thermometers were rented for the $R H$ brand; (2) the digital scales, measuring cups, measuring spoons, hand sealers, and thermometers were rented for the Ducrija brand; (3) making a new stickers that have good adhesive, digital scales, measuring cups, measuring spoons, and hand sealers were rented for the Green heart brand;(4) the 40x60 cm oven pan, redesigned label, and hand sealer were rented for the Laras brand; (5) the steaming pan $95 \times 95 \mathrm{~cm}$, Griddle 1 meter diameter, redesign label, hand sealer, and thermometer were rented for the DuaPutri brand; (6) the digital scales, measuring cups, spoons measuring, thermometers, hand sealers, making stickers that have good adhesive, redesign of labels, and assisting processing of aloe vera were rented for the KFD brand; (7) the Standard Operation Procedures (SOP) for the production of head rice were given for the Organic rice brand; (8) the digital scales, measuring cups, measuring spoons, freezers, molds of flowers for cassava chips from stainless steel, steaming pans, frying pan, frying spatula were rented for the Khadijah brand; (9) the $100 \mathrm{~L}$ size freezer and thermometer were rented for the Setia brand; (10) the Standard Operation Procedures (SOP) for producing milk goat powder was given to Gogoat brand. The photographs of equipment delivery are presented in Figure 7.
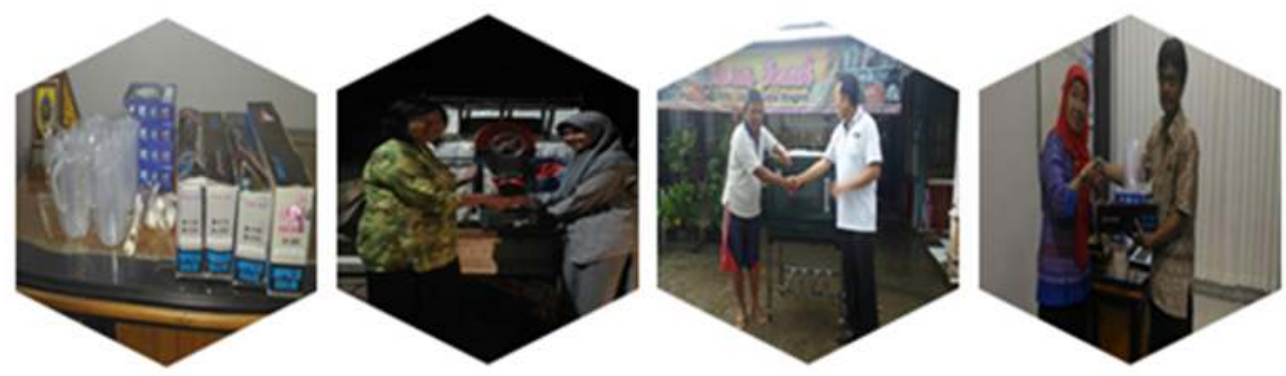

Figure 6. Handover of equipment leased to tenants 


\section{Monitoring and Evaluation}

To determine the impact and benefits of the assistance activities, monitoring and evaluation were carried out. The activity was carried out by conducting a pretest and post test and asking tenants to give testimony of the activities and expectations they wanted in the coming year.Pre test and post test are given to all tenants for all material provided. The material tested includes: product cost and business plan, industrial management, planting and processing of Aloe veraproducts, labeling of food products and legality. The post test results are presented in Table 1 and the results of testimonials and expectations are presented in Table 2.

Table 1. Post test value of mentoring activities

\begin{tabular}{|c|c|c|c|c|c|c|}
\hline \multirow[t]{2}{*}{ No tenant } & \multicolumn{5}{|c|}{ Materials } & \multirow[t]{2}{*}{ Average } \\
\hline & 1 & 2 & 3 & 4 & 5 & \\
\hline 1 & 100 & 92 & - & 60 & 80 & 83 \\
\hline 2 & 90 & 76 & - & 100 & 70 & 84 \\
\hline 3 & 80 & 83 & - & 75 & 50 & 72 \\
\hline 4 & 80 & 75 & - & 100 & 70 & 81.25 \\
\hline 5 & 90 & 76 & - & 60 & 70 & 74 \\
\hline 6 & 100 & 87 & 90 & 100 & 80 & 91.4 \\
\hline 7 & 80 & 91 & - & 80 & 80 & 82.75 \\
\hline 8 & 100 & 96 & - & 80 & 80 & 89 \\
\hline 9 & 90 & 76 & - & 100 & 80 & 86.5 \\
\hline
\end{tabular}

Materials information:

1. Simple book keeping \& business plan;

2. Industrial management;

3. Planting and processing of Aloe vera products;

4. Labeling of food products;

5. Legality

After following the assistance, tenant knowledge and skills increased. The increasing of knowledge ranges from 30-40\% where Mrs. Yawinah can make the nata aloe vera with a crunchy texture, although it still feels a little sour; Mr. Asmadi has succeeded in making crispy jackfruit chips, although there have been no changes in colors that are expected to become brighter; Mrs Asihareno longer felt pain when printing cassava chips. Mr. Maghfironi, Mrs Sri Lestari, Mrs. Nanik Sukoco already have a new brand because the brand that has been used has been registered by other producers. The three tenants also have a new packaging design resulting from incubation assistance.

Table 2. Testimony and tenant expectations

\begin{tabular}{|l|l|l|l|}
\hline No. & \multicolumn{1}{|c|}{$\begin{array}{c}\text { Owner name \& Merck } \\
\text { \&Produk }\end{array}$} & \multicolumn{1}{c|}{ Testimony } & \multicolumn{1}{c|}{ Expectation } \\
\hline 1 & $\begin{array}{l}\text { Asih Sapto Retno Nugroho } \\
\text { - Khadijah - Dumplings } \\
\text { (Pangsit) and cassava } \\
\text { crackers }\end{array}$ & $\begin{array}{l}\text { - The increasing of science } \\
\text { \& knowledge and } \\
\text { experience }\end{array}$ & $\begin{array}{l}\text { - To continue the assistance } \\
\text { - Marketing assistance }\end{array}$ \\
& $\begin{array}{l}\text { Encourage enthusiasm to } \\
\text { progress, innovate, and } \\
\text { succeed } \\
\text { Thank you for the } \\
\text { equipment } \\
\text { equipment loan }\end{array}$ & \\
& & \\
& & & \\
& & & \\
\end{tabular}




\begin{tabular}{|c|c|c|c|}
\hline No. & $\begin{array}{l}\text { Owner name \& Merck } \\
\text { \&Produk }\end{array}$ & Testimony & Expectation \\
\hline 2 & $\begin{array}{l}\text { Anik Purwanti - Ducrija - } \\
\text { mushroom chips }\end{array}$ & $\begin{array}{l}\text { - The increasing of science } \\
\text { - } \begin{array}{l}\text { The time for mentoring is } \\
\text { too short }\end{array}\end{array}$ & $\begin{array}{l}\text { - Further assistance is needed to } \\
\text { be able to innovate, correct } \\
\text { bookkeeping, complete } \\
\text { licensing, equipment that meets } \\
\text { the standards } \\
\text { - The equipments needed: deep } \\
\text { frying, spinner that has a timer, } \\
\text { continuous sealer, grinder, } \\
\text { generator set }\end{array}$ \\
\hline 3 & $\begin{array}{l}\text { Riyas Prihanto-Gogoat - } \\
\text { goat milk powder }\end{array}$ & Many benefits & - To continue the assistance \\
\hline 4 & $\begin{array}{l}\text { Asmadi - Setia Usaha } \\
\text { Mandiri - fruits chips }\end{array}$ & 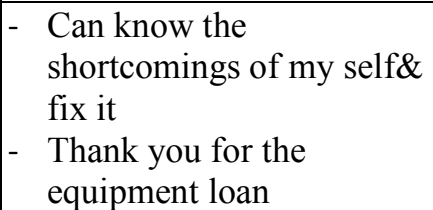 & $\begin{array}{l}\text { - The licensing assistance until } \\
\text { permission is issued } \\
\text { - Digital printing machine }\end{array}$ \\
\hline 5 & $\begin{array}{l}\text { Yawinah }- \text { KFD - turmeric } \\
\text { powder \&nata aloe vera }\end{array}$ & $\begin{array}{l}\text { - Got new knowledge to } \\
\text { improve the production } \\
\text { process of nata aloe vera } \\
\text { and have a longer shelf } \\
\text { life } \\
\end{array}$ & $\begin{array}{l}\text { - Packaging machine for powder } \\
\text { - Blender industry with capacity } \\
\text { of } 10 \mathrm{~kg} \\
\text { - Has a lid for plastic cup drinks } \\
\text { (nata aloe vera) }\end{array}$ \\
\hline 6 & $\begin{array}{l}\text { Herawati Utami Dewi - } \\
\text { kripik RH - various tuber } \\
\text { chips }\end{array}$ & $\begin{array}{l}\text { The increasing of science \& } \\
\text { knowledge }\end{array}$ & $\begin{array}{l}\text { Corrugated cutting machine like } \\
\text { model taro/citato }\end{array}$ \\
\hline 7 & $\begin{array}{l}\text { Sri Lestari-Laras (New } \\
\text { Laras) - ampyang, } \\
\text { balongkete }\end{array}$ & The increasing of science & $\begin{array}{l}\text { - business increases, income } \\
\text { increases } \\
\text { - add outlets: souvenirs of the city } \\
\text { of Sragen to accommodate the } \\
\text { products of others of SMEs }\end{array}$ \\
\hline 8 & $\begin{array}{l}\text { Maghfironi - duaputri } \\
\text { (duajagung) - } \\
\text { empingmarning, corn rice }\end{array}$ & $\begin{array}{l}\text { The increasing of } \\
\text { knowledge about } \\
\text { processing, licensing, } \\
\text { labeling }\end{array}$ & $\begin{array}{l}\text { - the assistance is continued until } \\
\text { the tenant can be independent } \\
\text { - Payment for an in wall tenant is } \\
\text { charged after } 6 \text { months later } \\
\text { - Need to get a capital } \\
\text { - Provision of production } \\
\text { equipment assistance }\end{array}$ \\
\hline 9 & $\begin{array}{l}\text { Nanik Sukoco - Green } \\
\text { heart ( OVJ - Olahan } \\
\text { Vegeta Jaya) - vegetable } \\
\text { chips }\end{array}$ & $\begin{array}{l}\text { - } \text { The increasing of } \\
\text { knowledge } \\
\text { - } \text { Can overcome the existing } \\
\text { processing problems } \\
\text { - } \text { More business spirit } \\
\end{array}$ & $\begin{array}{l}\text { - Spinner that has speed and time } \\
\text { control } \\
\text { - The assistance of vakum frying }\end{array}$ \\
\hline
\end{tabular}

\section{CONCLUSION}

Tenants have felt that food processing assistance activities at the STP Ganesha Sukawati Sragen are very useful. These activities have increased the knowledge, insight, and skills of the tenants. Tenants have been expecting that the assistance will be continued until they are fully mastered and independent. This can be seen in the testimonies and expectations conveyed by tenants. Tenants at STP Ganesha Sukawati Sragen have the spirit, will, ability, and hard effort to move forward. All tenants follow activities from the beginning to the end. They are serious in learning all the material provided. After that they also tried to apply what they had acquired in their business activities. The tenants in STP 
Ganesha Sukawati Sragen, especially in the field of food processing, are assets for Sragen Regency to advance their own business and Sragen Regency in general.

From the assistance activities that have been carried out, tenants are (1) Improving the quality of their products as indicated by the crispy texture of aloe vera, a label with a new design that contains more complete information in accordance with labeling regulations; (2) Improving management and business governance by preparing business bookkeeping and the existence of SOPs for the process of food processing; (3) the legality aspect of the tenant's business is in the preparation stage; and (4) the establishment of a viable business development business plan.

\section{ACKNOWLEDGEMENT}

This activity was funded by the Ministry of Research, Technology and Higher Education Directorate General of Institutional Science, Technology and Higher Education, in accordance with the Work Agreement Number: 04a / SPK / PL / DKSTPL / IX / 2016, dated September $29^{\text {th }}, 2016$.

\section{REFERENCES}

Agustinus. (2010). Pengaruh konsentrasi kalsiuml aktat glukonat terhadap sifat fisik okimiad anorganoleptik susu beras merah kedelai. Skripsi. Progarm Studi Teknologi Pangan Fakultas Teknologi Pertanian Universitas Katolik Widya Mandala Surabaya.

Ahmad, F. dan Washilah. (2009). Akuntansi Biaya. Edisi 2. Jakarta : Salemba Empat.

Badan Pengawas Obat dan Makanan. (2012). Peraturan Kepala Badan Pengawas Obat Dan Makanan Republik Indonesia Nomor Hk.03.1.23.04.12.2205 Tahun 2012 Tentang Pedoman Pemberian Sertifikat Produksi Pangan Industri Rumah Tangga.

Badan Pengawas Obat dan Makanan. (2017). Peraturan Kepala Badan Pengawas Obat dan Makanan nomor 27 tentang pendaftaran panganolahan. BPOM

Ony, W.L., DW. Firdaus, SD. Anggadini. (2012).Akuntansi Biaya.Edisi 1.Yogyakarta-Graha Ilmu.

Peraturan Pemerintah Republik Indonesia nomor 69 tahun 1999 tentang Label dan Iklan PanganPresiden Republik Indonesia.

Peraturan kepala badan pengawas obat dan makanan republic Indonesia nomor 13 tahun 2016 tentang pengawasan klaim pada label dan iklan panganolahan

Permendag No.22/M-DAG/PER/5/2010 tentang Kewajiban Label pada Barang.

Perpres No. 2 Tahun 2015: pemerataan pembangunan diantaranya dengan membangun 100 STP di seluruh Indonesia.

Rahmawati, Sabariman. M, Utomo. S. (2017). Pemberdayaan KWT Citra Mandiri melalui Pengembangan Produk Olahan Berbasis Aloe vera di KecamatanTapos, Depok. Jurnal Agrokreatif Vol 3 (1): 72-78. ISSN 2460-8572, EISSN 2461-095X

Rajeswari, R., Umadevi, M., Rahale, C. S., Pushpa, R., Selvavenkadesh, S., Kumar, K. S., \& Bhowmik, D. (2012). Aloe vera: the miracle plant its medicinal and traditional uses in India. Journal of Pharmacognosy and Phytochemistry, 1(4), 118-124.

UU 18/2002: Sisnas P3 IPTEK:Alih teknologi kekayaan intelektual dan hasil litbang. 
Undang-Undang Republik Indonesia Nomor 18 Tahun 2012 Tentang Pangan

Undang-undangNo. 15 Tahun 2001 tentang Merek (UUM).

www.lautanindonesia.com/serbarasa/artikel/in-topic/lidah-buayaaloevera-tanaman-hias-yang-saratmanfaat. (2008). BudidayaLidahBuaya. http://www.lautanindonesia.com/serbarasa/artikel/intopic/lidah-buayaaloevera-tanaman-hias-yang-sarat-manfaat, diaksestanggal 19 Oktober 2008 